\title{
Review \\ The Extraction of $\beta$-Carotene from Microalgae for Testing Their Health Benefits
}

\author{
Jing Wang ${ }^{1,+}$, Xinge $\mathrm{Hu}^{2,+}$, Junbin Chen ${ }^{3}$, Tiannan Wang ${ }^{2}$, Xianju Huang ${ }^{1}{ }^{\mathbb{D}}$ and Guoxun Chen ${ }^{2, *} \mathbb{C}$ \\ 1 College of Pharmacy, South-Central University for Nationalities, Wuhan 430074, China; \\ 18772842249@163.com (J.W.); xianju@mail.scuec.edu.cn (X.H.) \\ 2 Department of Nutrition, University of Tennessee at Knoxville, Knoxville, TN 37996, USA; \\ xhu25@vols.utk.edu (X.H.); twang14@vols.utk.edu (T.W.) \\ 3 School of Public Health, Southern Medical University, Guangzhou 510515, China; box@i.smu.edu.cn \\ * Correspondence: gchen6@utk.edu; Tel.: +1-865-974-6257 \\ + These authors contributed equally to this work.
}

check for updates

Citation: Wang, J.; Hu, X.; Chen, J.; Wang, T.; Huang, X.; Chen, G. The Extraction of $\beta$-Carotene from Microalgae for Testing Their Health Benefits. Foods 2022, 11, 502. https:// doi.org/10.3390/foods11040502

Academic Editor: M. Angela

A. Meireles

Received: 26 January 2022

Accepted: 9 February 2022

Published: 10 February 2022

Publisher's Note: MDPI stays neutral with regard to jurisdictional claims in published maps and institutional affiliations.

Copyright: (C) 2022 by the authors. Licensee MDPI, Basel, Switzerland. This article is an open access article distributed under the terms and conditions of the Creative Commons Attribution (CC BY) license (https:// creativecommons.org/licenses/by/ $4.0 /)$.

\begin{abstract}
A$, and can be converted into vitamin A (retinol), which plays essential roles in the regulation of physiological functions in animal bodies. Microalgae synthesize a variety of carotenoids including $\beta$-carotene and are a rich source of natural $\beta$-carotene. This has attracted the attention of researchers in academia and the biotech industry. Methods to enrich or purify $\beta$-carotene from microalgae have been investigated, and experiments to understand the biological functions of microalgae products containing $\beta$-carotene have been conducted. To better understand the use of microalgae to produce $\beta$-carotene and other carotenoids, we have searched PubMed in August 2021 for the recent studies that are focused on microalgae carotenoid content, the extraction methods to produce $\beta$-carotene from microalgae, and the bioactivities of $\beta$-carotene from microalgae. Articles published in peer-reviewed scientific journals were identified, screened, and summarized here. So far, various types and amounts of carotenoids have been identified and extracted in different types of microalgae. Diverse methods have been developed overtime to extract $\beta$-carotene efficiently and practically from microalgae for mass production. It appears that methods have been developed to simplify the steps and extract $\beta$-carotene directly and efficiently. Multiple studies have shown that extracts or whole organism of microalgae containing $\beta$-carotene have activities to promote lifespan in lab animals and reduce oxidative stress in culture cells, etc. Nevertheless, more studies are warranted to study the health benefits and functional mechanisms of $\beta$-carotene in these microalgae extracts, which may benefit human and animal health in the future.
\end{abstract}

Keywords: microalgae; $\beta$-carotene; carotenoids; vitamin A; extraction; bioactivities

\section{Introduction}

Microalgae are a large group of photosynthetic microorganisms including unicellular prokaryotic and eukaryotic organisms [1]. They are widely distributed in land and sea, and are rich sources of nutrients [2,3]. The size of microalgae ranges from 0.2 to $2 \mu \mathrm{m}$ (picoplankton) up to $100 \mu \mathrm{m}$ or higher (filamentous forms) [4]. They are mainly autotrophic, but a few microalgae are heterotrophic due to the degeneration of chloroplasts [5]. Microalgae perform photosynthesis to produce organic molecules and support their rapid growth. Their short mitotic time allows them to be produced on a large scale for the extraction of bioactive compounds, which have a lot of biological activities in functional food and nutraceuticals, as summarized in an edited book [6]. Microalgae exist in diverse environmental conditions and are rich sources of biomolecules such as proteins, fat, and carbohydrates. Microalgae culture can be industrialized to produce compounds with commercial value $[7,8]$. As microalgae synthesize lipids, carbohydrates, proteins, vitamins, and pigments, they are a food source for plankton [9]. Microalgae are also considered a candidate to fix carbon 
dioxide for biofuel production, and to sequestrate nitrogen oxides and sulfur oxides for sewage treatment and environmental protection [10]. Due to the immature technology and high production cost, microalgae biofuel has not been industrialized [11]. On the other hand, outbreaks of harmful or toxic microalgae can cause red tides and algal blooms in eutrophication [12].

Recently, microalgae have attracted intensive research interests due to their commercial potential [13]. The diverse bioproducts from microalgae can be widely used for pharmaceuticals, nutraceuticals, food colorants, and animal feed. At present, microalgae in the following phyla: Cyanophyta, Chlorophyta, Chrysophyta, and Erythrophyta have been cultivated or produced in large quantities. The common microalgae with economic values include Haematococcuspluvialis, chlorella, and spirulina [14,15]. Compared with the higher plants, microalgae present a series of advantages such as faster growth, higher yield, and shorter cultivation time. Therefore, they are widely used in the industrial production of bioactive compounds [16]. It has been estimated that more than 200 bioactive compounds can be extracted from cyanobacteria, and thousands from eukaryotic microalgae [16]. For example, marine organisms accumulate vitamin D through the consumption of (micro)algae [17]. In addition, Spirulina is also called a "superfood" because of its contents of vitamins $\left(\mathrm{E}, \mathrm{K}, \mathrm{B}_{1}, \mathrm{~B}_{2}, \mathrm{~B}_{3}, \mathrm{~B}_{6}\right.$, and $\left.\mathrm{B}_{12}\right)$, proteins (phycocyanin, allophycocyanin, and phycoerythrin) and other bioactive compounds ( $\gamma$-linolenic acid, palmitic acid, calcium, selenium, zinc, etc.) [18,19].

Microalgae are one source of carotenoids. Spirulina, Chlorella, Dunaliella, and Haematococcus can produce fucoxanthin, violaxanthin, neoxanthin, $\alpha$-carotene, $\beta$-carotene, and lutein in large quantities, which are considered provitamin A [20]. $\beta$-carotene, a ubiquitous pigment concerned with the photosynthetic process in microalgae, has shown a variety of bioactivities [21]. It is the most abundant dietary provitamin A that can be converted into vitamin A (VA, retinol), which is a micronutrient for human health [22]. The raw extract and pure compound of $\beta$-carotene from microalgae have been studied and shown to have biological activities such as hepatotoprotection, anti-obesity, anti-inflammation, immunomodulation, and anti-cancer [23-26]. For example, supplementations of $\beta$-carotene extracts from Spirulina and Dunaliella have been shown to reduce the activity of transaminases in CC14-induced hepatic-damaged Wistar rats [27]. Spirulina is rich in carotenoids, and the supplementation of Spirulina biomass raises the antioxidant enzymes in the serum and liver of Wistar rats, showing its antioxidant activity [28].

To date, various methods such as solvent extraction and supercritical fluid extraction have been developed to extract carotenoids from microalgae for mass production [29]. Despite previous concerns such as efficiency, high solvent-consumption, and long treatment times [30], methods have been evolved to solve these problems. For example, these methods have been used to extract carotenoids from vegetables [31]. It was estimated that about $50 \%$ of total $\beta$-carotene in Scenedesmus almeriensis can be extracted using a supercritical carbon dioxide extraction method [32]. The aim of this review is to summarize $\beta$-carotene, its extraction methods, its health value, and the presence of other types of carotenoids in different microalgae sources. In addition, we wanted to evaluate the studies that investigated bioactivities of $\beta$-carotene obtained from microalgae. Therefore, we searched the PubMed database in August 2021, retrieved relevant peer-reviewed articles that discussed the extraction methods of $\beta$-carotene, and evaluated the bioactivities of extracts containing $\beta$-carotene and other carotenoids from microalgae in cell and animal models. We hope to identify gaps for the future use of $\beta$-carotene and other carotenoids in the promotion of human health.

\section{Vitamin A (VA) and $\beta$-Carotene}

\subsection{VA and Its Metabolism}

VA (retinol) is essential for the general health of humans [33]. Molecules with VA activities include preformed VA and provitamin A. Preformed VA in the forms of retinyl esters (REs) and retinol can be found in foods from animal products [22]. Liver and fish oil 
have the highest concentration of preformed VA provitamin A carotenoids, mainly from plants and microalgae [33]. The most important provitamin A carotenoid is $\beta$-carotene, which is present abundantly in carrots and yellow and green leafy vegetables [33]. Other provitamin A carotenoids include $\alpha$-carotene and $\beta$-cryptoxanthin. Carotenoids are also solubilized into micelles in the intestinal lumen from which they are absorbed into duodenal mucosal cells [22]. Carotenoids (such as $\beta$-carotene) after absorption can be converted into retinal within the enterocytes or absorbed and transported to hepatocytes for cleavage into retinal (retinaldehyde), which can be reduced into retinol [34].

In the small intestine lumen, dietary REs are hydrolyzed into free retinol and fatty acids by the intraluminal retinol ester hydrolases [34] and nonspecific pancreatic enzymes such as pancreatic triglyceride lipase and cholesterol ester hydrolase. Retinol and fatty acids are absorbed into enterocytes [35], where they are esterified mainly by lecithin:retinol acyltransferase to form REs and packed into chylomicrons. REs and carotenoids in chylomicrons can be taken up directly by peripheral tissues [22]. The remaining REs and carotenoids in chylomicron remnants are taken by the liver [22].

The plasma retinol concentration is under homeostatic control, which reflects the dietary VA intake and hepatic VA reserve [36]. To meet the tissue needs for VA, retinol released from the liver binds to retinol binding protein 4 (RBP4), which is synthesized in hepatocytes and responsible for VA transport in the body [22]. Retinol binds to RBP4 in the blood, and cellular retinol binding proteins in cells [37,38]. Retinol can be oxidized by retinol dehydrogenase to retinal (retinaldehyde), which can be reduced by alcohol dehydrogenases/retinol dehydrogenases to retinol again or oxidized by retinaldehyde dehydrogenase into retinoic acid (RA). RA enters into the cell nucleus and regulates gene expressions through activations of transcription factors such as RA receptors and retinoid $X$ receptors, which control cell morphogenesis, differentiation, proliferation, etc. [34]. Further oxidization of RA mediated by Cyp26A1 and Cyp26B1 generates polar compounds without the ability to activate transcription. Retinol can be esterified by lecithin:retinol acyltransferase into REs for storage [39,40]. When the liver VA content rises, the excretion of its metabolites in the bile increases. Other VA metabolites are excreted in the urine [22]. In addition, VA can act as an antioxidant to reduce free radicals [41].

In 2001, the American Institute of Medicine defined the Recommended Dietary Allowance (RDA) of VA in micrograms ( $\mu \mathrm{g}$ ) of retinol activity equivalent (RAE) to illustrate the different biological activities of retinol and provitamin A carotenoids. One $\mu \mathrm{g}$ of RAE is equivalent to $1 \mu \mathrm{g}$ of retinol, $2 \mu \mathrm{g}$ of supplementary $\beta$-carotene, $12 \mu \mathrm{g}$ of dietary $\beta$-carotene, or $24 \mu \mathrm{g}$ of dietary $\alpha$-carotene or $\beta$-cryptoxanthin [33]. The RDAs are $900 \mu \mathrm{g}$ RAE for men, $700 \mu \mathrm{g}$ RAE for women, and $770 \mu \mathrm{g}$ RAE for pregnant women aged between 19 and 50 years old [33]. Adequate VA is defined as plasma retinol levels $>1.05 \mu \mathrm{mol} / \mathrm{L}$. A retinol level $<0.7 \mu \mathrm{mol} / \mathrm{L}$ is defined as VA deficiency.

\section{2. $\beta$-Carotene}

Carotenes are structurally different polyunsaturated hydrocarbons containing 40 carbons and synthesized by plants and microalgae. There are 1167 natural carotenoids, in which 38 50 can be considered as provitamin A, including $\beta$-carotene, $\beta$-cryptoxanthin and $\alpha$-carotene, etc. [42]. The most abundant dietary provitamin A carotenoid is $\beta$-carotene, which has eight isoprene units and two $\beta$-ionone-ring at both ends [43]. Figure 1 shows the structures and some physicochemical properties of $\alpha$-carotene (A), $\beta$-carotene (B), $\beta$-carotene 5,6-epoxide (C), 9-cis- $\beta$-carotene (D), 9-cis- $\beta$-carotene (E), and 9-cis- $\beta$-carotene $(\mathrm{F})$, which can be identified in microalgae. Due to its absorbance of light, $\beta$-carotene is responsible for the color in the fungi, fruit, and vegetables such as red pepper and orange [44]. Dietary $\beta$-carotene is mainly absorbed in the duodenum portion of the small intestine, a process that is probably mediated by the class B scavenger receptor [45]. 


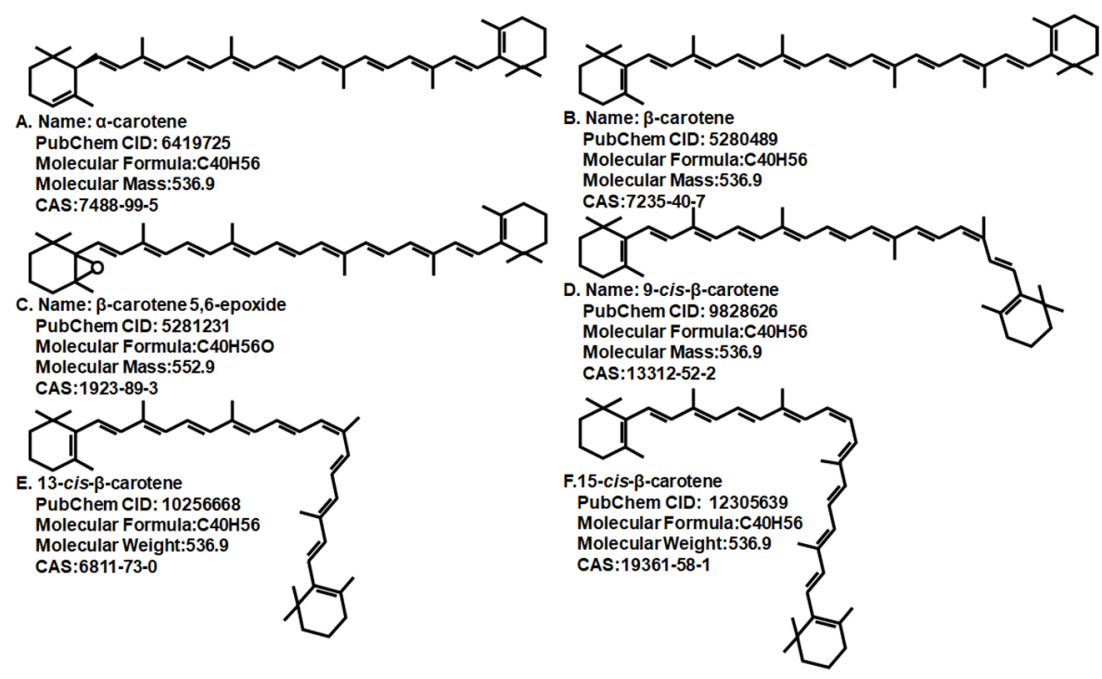

Figure 1. Structures and some physicochemical properties of $\alpha$-carotene (A), $\beta$-carotene (B), $\beta$-carotene 5,6-epoxide (C), 9-cis- $\beta$-carotene (D), 9-cis- $\beta$-carotene (E), and 9-cis- $\beta$-carotene (F).

As $\beta$-carotene can be converted to retinol, its metabolism has been studied extensively. The cleavage of $\beta$-carotene symmetrically or asymmetrically leads to the production of retinal (retinaldehyde), which is reduced to retinol [46]. $\beta$-carotene cleavages primarily occur in enterocytes and hepatocytes. In the presence of oxygen, $\beta$-carotene-15,15'-oxygenase (BCO1) can symmetrically oxidize the $15,15^{\prime}$ double bond of $\beta$-carotene and generate two molecules of retinal (retinaldehyde). The $9,10^{\prime}$ double bond of $\beta$-carotene is asymmetrically cleaved by $\beta$-carotene $9^{\prime}, 10^{\prime}$-oxygenase 2 (BCO2), which generates a $\beta$-apo- $10^{\prime}$-carotenal. Other asymmetrical cleaves may also occur with or without enzyme catalysis and yield $\beta$-apo- $8^{\prime}$-carotenal or $\beta$-apo-14'-carotenal, but the enzymes involved in these reactions remain unidentified $[47,48]$. Recent research suggested that the products of the asymmetric cleavage can be further cleaved by $\beta$-carotene-15,15'-oxygenase, which results in the production of retinal [39]. The mice with $\mathrm{BOC} 1, \mathrm{BCO} 2$, and $\mathrm{BCO} 1 / \mathrm{BCO} 2$ knockout have been compared. BOC1 knockout appears to disrupt the $\beta$-carotene homeostasis, and the production of $\beta$-apo- $10^{\prime}$ carotenol is BCO2-dependent. $\beta$-apo-10' carotenol can be esterified and transported as retinol [49].

\section{Microalgae as a Source of Carotenoids and Other Bioactive Compounds}

\subsection{The Applications of Carotenoids and Other Components Extracted from Microalgae}

Raw extracts and pure compounds from microalgae have been studied and shown to have numerous applications and biological activities such as anti-obesity, anti-diabetes, anti-inflammation, immunomodulation, and anti-cancer $[24,25,50]$. For example, supplementation of Spirulina has been shown to reduce the body weight of overweight and obese human subjects [51,52] and increase the lipoprotein lipase activity and insulin secretion in hyperlipidemic rats [53]. Spirulina is rich in carotenoids, and the supplementation of Spirulina biomass raises antioxidant enzymes in the serum and liver of Wistar rats, showing its antioxidant activity [28].

Carotenoids have been considered as antioxidants, and they act to block the damages initiated by reactive oxygen species and maintain the integrity of cell membrane and organelles [54]. This has led people to believe that $\beta$-carotene and other carotenoids may help to reduce the risk chronic diseases, such as diabetes, cancer, and cardiovascular diseases [54].

Carotenoids including $\alpha$ - and $\beta$-carotene and $\alpha$-tocopherol are detected in the human dermis and epidermis, as reviewed in [55]. The presence of carotenoids in the skin is thought to protect damages caused by the photooxidative processes. Carotenoids and other antioxidants can eliminate reactive oxygen species and absorb UV light, which can be achieved through dietary supplements and tropical applications [55]. In addition to $\beta$-carotene, other carotenoids can be extracted from microalgae. For example, astaxanthin 
can be extracted from microalga Haematococcus pluvialis. It has been shown that astaxanthin can decrease the oxidative stress and reduce damage caused by oxidative metabolism to skin and delay skin aging [56]. At the same time, Astaxanthin can also help repair damaged skin [57] and accelerate wound healing in mice [58]. Therefore, $\beta$-carotene and other antioxidants play important roles to maintain skin health.

Oxidized $\beta$-carotene copolymers may act as an antibacterial growth promoter to enhance the feed intake and growth in broilers [59]. The oxidized $\beta$-carotene copolymers at 2 ppm and higher supplemented in feeds improved feed conversion, average daily gain, feed intake, and body weight in tested broilers [59].

Carotenoids extracted from microalgae can be used as a pigment duo to its orange or red color. They are safer and healthier natural dyes than artificial dyes and are commonly used in the food and cosmetic industries [60]. $\beta$-carotene has been commonly added to soft drinks, cheese, and butter for coloring [61]. On the other hand, carotenoids such as astaxanthin have been used as an additive in feed to enhance the color of salmon flesh $[61,62]$. Canthaxanthin extracted from Chlorella zofingiensis is a natural dye and is commonly used as a feed additive to intensify the skin color of fish, including salmonid and crustacean [63].

Lutein is another carotenoid xanthophylls mainly extracted from Chlorella protothecoides. Lutein can be used to protect eyes from damage caused by short-wavelength visible light phototoxicity, thereby decreasing the risk of having cataract and age-related macular degeneration [64]. Lutein can also be used as a feed additive to improve the color of poultry egg yolks and feathers [65].

In addition to carotenoids, proteins and polyunsaturated fatty acids (PUFA) from microalgae can also have health benefits. For example, phycocyanin, a water-soluble and non-toxic protein isolated from Spirulina, can decrease the plasma levels of total cholesterol, triglycerides, and malondialdehyde in diabetic mice [66]. Phycocyanin exhibits anti-inflammatory activities through inhibiting cyclooxygenase-2 expression and cytokines production in lipopolysaccharide-activated macrophages $[67,68]$. Furthermore, microalgae are also one source of $\omega 3$ PUFAs, such as eicosapentaenoic acid (EPA) and docosahexaenoic acid (DHA). Spirulina and Chlorella are valuable sources of w3-PUFAs [69]. To date, microalgae Cryptocodinium cohnii has been used to produce DHA-rich oil [70]. Microalgae of the genus Nannochloropsis are already exploited in aquaculture for their high content in PUFAs [70]. Studies have shown that PUFAs can reduce the incidence of cardiovascular disease [71].

\subsection{Studies on the Carotenoid Content in Microalgae and Bioactivities}

The carotenoids in microalgae include astaxanthin, $\beta$-carotene, canthaxanthin, zeaxanthin, purple xanthin, lutein, fucoxanthin, etc. $\beta$-carotene and zeaxanthin are widely distributed. High levels of $\beta$-carotene are present in Dunaliella salina [72,73]. The content of carotenoids in microalgae is high, which usually account for $0.1-0.2 \%$ of the total dry matter of microalgae [74]. Dunaliella salina produces up to $13 \%$ of its biomass as $\beta$-carotene. The content of astaxanthin was up to $7 \%$ of the biomass in Haematococcus pluvialis, and nearly $5 \%$ of the biomass in Coalstrella striolata [14]. Table 1 shows the contents of $\alpha$-carotene, $\beta$-carotene, $\beta$-carotene 5,6-epoxide, 9 -cis- $\beta$-carotene, 13 -cis- $\beta$-carotene, and 15 -cis- $\beta$-carotene that are identified in some microalgae. All the studies used high-performance liquid chromatography (HPLC) to analyze the presence of the indicated $\alpha$-carotene, $\beta$-carotene, and its derivative or isomers. Some of them used mass spectrometry to further identify them [42,75-77]. 
Table 1. Contents of $\alpha$-carotene, $\beta$-carotene, $\beta$-carotene-5,6-epoxide, 9 or 13 or 15 -cis- $\beta$-carotene, and total carotenoids in different microalgae sources.

\begin{tabular}{|c|c|c|c|c|c|c|c|}
\hline Strains & Units/Analysis & $\alpha$-Carotene & $\beta$-Carotene & $\beta$-Carotene-5,6-epoxide & 9,13 or 15 -cis- $\beta$-carotene & Total & Ref. \\
\hline Chlorella sorokiniana & $\mu \mathrm{g} / \mathrm{g}$ DW/HPLC-PDA-MS & 71 & 156 & \multirow[b]{2}{*}{13} & \multirow{2}{*}{$\begin{array}{c}42(9-c i s) \\
54 \text { (9-cis), } 16 \text { (13-cis) }\end{array}$} & 1408 & \multirow{2}{*}[75]{} \\
\hline Scenedesmus bijuga & for analysis & 41 & 166 & & & 1196 & \\
\hline Chlorella zofingiensis & & 0.09 & 0.29 & & & & \multirow{5}{*}{ [76] } \\
\hline Selenastrum bibraianum & $\mathrm{mg} / \mathrm{g}$ & 0.08 & 0.16 & & & & \\
\hline Desmodesmus denticulatus var. linearis & DW/HPLC-APCI-MS/MS & 0.21 & 0.4 & & & & \\
\hline Coelastrum sphaericum & for analysis & & 0.11 & & & & \\
\hline Mougeotia sp. & & & 0.14 & & & & \\
\hline Scenedesmus & \multirow{3}{*}{$\begin{array}{c}\mu \mathrm{g} / \mathrm{g} \text { DW } / \text { HPLC-PDA- } \\
\text { MS/MS for } \\
\text { analysis }\end{array}$} & \multirow[t]{3}{*}{42} & 778 & 21 & 124 (9-cis), 47 (13-cis) & 2651 & \multirow{3}{*}{ [42] } \\
\hline Chlorella & & & 352 & 49 & 40 (9-cis), 17 (13-cis) & 1977 & \\
\hline Aphanothece & & & 368 & 62 & 46 (9-cis), 17 (13-cis) & 1399 & \\
\hline Nannochloropsis limnetica & \multirow{8}{*}{$\begin{array}{l}\text { matograms for } \\
\text { analysis }\end{array}$} & \multirow{8}{*}{0.084} & 0.28 & & & 3.0 & \multirow{8}{*}{ [78] } \\
\hline Mougeotia. salina & & & 2.22 & & & 5.1 & \\
\hline Nannochloropsis oceanica & & & $0.1-1.7$ & & & & \\
\hline Nannochloropsis sp. & & & 0.67 & & & 8.6 & \\
\hline Nannochloropsis oceanica & & & $0.3-1.1$ & & & & \\
\hline Nannochloropsis oculata & & & $0.07-0.14$ & & & & \\
\hline Mougeotia salina & & & 2.22 & & & & \\
\hline Nannochloropsis spp. & & & 0.3 & & & & \\
\hline Porphiridium cruentum & \multirow{5}{*}{$\begin{array}{c}\mathrm{mg} / 100 \mathrm{~g} \mathrm{DW} / \mathrm{HPLC} \\
\text { chromatograms for } \\
\text { analysis }\end{array}$} & \multirow{5}{*}{42} & 53 & & & 167 & \multirow{5}{*}{ [79] } \\
\hline Isochrysis galbana & & & 53 & & & 1760 & \\
\hline Phaeodactylum tricornutum & & & 34 & & & 1022 & \\
\hline Tetraselmis suecica & & & 43 & & & 297 & \\
\hline Nannochloropsis gaditana & & & 100 & & & 447 & \\
\hline Dunaliella tertiolecta & \multirow{2}{*}{$\begin{array}{c}\mathrm{mg} / \mathrm{g} \\
\text { DW/HPLC-APCI-MS/MS } \\
\text { for analysis }\end{array}$} & 0.04 & 0.62 & & $\begin{array}{c}0.13 \text { (9-cis), } 0.06 \text { (13-cis) } \\
0.02 \text { (15-cis) }\end{array}$ & 3.4 & \multirow[t]{2}{*}{ [77] } \\
\hline Heterochlorella luteoviridis & & 0.47 & 0.50 & & $\begin{array}{c}0.13 \text { (9-cis), } 0.12(13-c i s) \\
0.04(15-c i s)\end{array}$ & 3.47 & \\
\hline
\end{tabular}


Table 1. Cont.

\begin{tabular}{|c|c|c|c|c|c|c|c|}
\hline Strains & Units/Analysis & $\alpha$-Carotene & $\beta$-Carotene & $\beta$-Carotene-5,6-epoxide & 9,13 or 15 -cis- $\beta$-carotene & Total & Ref. \\
\hline $\begin{array}{l}\text { Eustigmatos magnus } \\
\text { Eustigmatos polyphem } \\
\text { Eustigmatos vischeri } \\
\text { Vischeria helvetica } \\
\text { Vischeria punctata } \\
\text { Vischeria stellata }\end{array}$ & $\begin{array}{l}\mathrm{mg} / \mathrm{g} \text { DW for total and \% } \\
\text { of total carotenoids for } \\
\text { individuals/HPLC } \\
\text { chromatograms for } \\
\text { analysis }\end{array}$ & & $\begin{array}{l}53 \\
51 \\
53 \\
58 \\
57 \\
62\end{array}$ & & & $\begin{array}{l}25 \\
14 \\
19 \\
25 \\
33 \\
55\end{array}$ & {$[80]$} \\
\hline Chlorella pyrenoidosa & $\begin{array}{l}\mu \mathrm{g} / \mathrm{g} \mathrm{DW} / \mathrm{HPLC} \\
\text { chromatograms for } \\
\text { analysis }\end{array}$ & 2466 & 2155 & & 580 (9-cis) & & [81] \\
\hline
\end{tabular}

Note: APCI, atmospheric pressure chemical ionization; DW, dry weight; HPLC, high-performance liquid chromatography; MS, mass spectrometry; PDA, photodiode array; Ref., references. 
The initial research on using microalgae as a potential commercial source of $\beta$-carotene began in the 1960s [82]. Later on, microalgae have been considered as a commercial source of glycerol [83]. So far, chemically synthesized carotenoids are the major products, which are about $97-98 \%$ of the total market [84]. The synthetic $\beta$-carotene products contain only all-trans isomer [85]. Molecules with $\beta$-carotene activities in microalgae are mixture of all-trans ( $\beta$-carotene in this manuscript) and cis isomers. The cis isomers have stronger antioxidant capacities than the all-trans one. Table 1 summarizes the contents of $\alpha$-carotene, $\beta$-carotene, and its derivatives, $\beta$-carotene 5,6 -epoxide, 9 -cis- $\beta$-carotene, 9 -cis- $\beta$-carotene, and 9 -cis- $\beta$-carotene in microalgae. Obtaining carotenoids from natural raw materials is favored by more and more consumers. The production of natural carotenoids to increase product values has become the new direction for researchers. Companies in Australia, Israel, and the United States of America have started to produce $\beta$-carotene from microalgae [85]. In the 1980s, $\beta$-carotene extracted from microalgae and dried powders of microalgae rich in $\beta$-carotene were marketed by companies in the United States of America and Australia [86]. The products have been used as coloring for natural foods and animal feeds, and natural $\beta$-carotene supplementation [62]. In addition to $\alpha$ - and $\beta$-carotene, other carotenoids are also detected in various microalgae, as shown in Table 2. HPLC is used to analyze the presence of those carotenoids. Mass spectrometry is also used in some studies shown in Table 2 [42,75-77]. As we can see, the contents of carotenoids such as lutein, zeaxanthin and antheraxanthin are very high in certain microalgae sources. Although more than 40,000 microalgae species have been identified, only a few of them have been used in commercial microalgae production for obtaining carotenoids and proteins, showing the future potential expansion of the field [9]. 
Table 2. Contents of carotenoids other than $\alpha$ - and $\beta$-carotene in different microalgae sources.

\begin{tabular}{|c|c|c|c|c|c|c|c|c|c|c|c|c|c|c|c|c|c|}
\hline Strains & Unit/Analysis & Total & Lutein & Zea & Anth & Luth & Vio & Vau & Fuco & Ech & Asx & Neo & Crx & $\operatorname{Ddx}$ & Dtx & Ctx & Ref. \\
\hline Chlorella sorokiniana & \multirow{2}{*}{$\mu \mathrm{g} / \mathrm{g}$ DW/HPLC-PDA-MS for analysis } & 1408 & 909 & 45 & & & 54 & & & & & 131 & & & & & \multirow[t]{2}{*}{ [75] } \\
\hline Scenedesmus bijuga & & 1196 & 671 & 36 & & & 33 & & & 15 & & 151 & & & & & \\
\hline Chlorella zofingiensis & \multirow{5}{*}{$\begin{array}{c}\mathrm{mg} / \mathrm{g} \text { DW/HPLC-APCI-MS/MS for } \\
\text { analysis }\end{array}$} & & 0.49 & & & & & & & & 5.7 & & 0.11 & & & 0.18 & \multirow{5}{*}{ [76] } \\
\hline Selenastrum bibraianum & & & 1.73 & & & & & & & & 0.41 & & 1.34 & & & 0.03 & \\
\hline $\begin{array}{l}\text { Desmodesmus denticulatus var. } \\
\text { linearis }\end{array}$ & & & 8.46 & & & & & & 0.07 & & & & & & & & \\
\hline Coelastrum sphaericum & & & 2.75 & & & & & & & & 15 & & 0.42 & & & 0.21 & \\
\hline Mougeotia sp. & & & 1.56 & & & & & & 0.92 & & 3.48 & & 0.73 & & & & \\
\hline Scenedesmus & \multirow{3}{*}{$\begin{array}{l}\mu \mathrm{g} / \mathrm{g} \text { DW/HPLC-PDA-MS/MS for } \\
\text { analysis }\end{array}$} & 2651 & 776 & 332 & 38 & 55 & 32 & & & 273 & & 61 & 24 & & 21 & 10 & \multirow{3}{*}[42]{} \\
\hline Chlorella & & 1977 & 184 & 271 & 19 & 17 & 13 & & & 716 & & 21 & 15 & & 22 & 104 & \\
\hline Aphanothece & & 1399 & 33 & 103 & 14 & & & & & 597 & & & 10 & & & 52 & \\
\hline Nannochloropsis limnetica & \multirow{3}{*}{$\begin{array}{c}\mathrm{mg} / \mathrm{g} \text { DW/HPLC chromatograms for } \\
\text { analysis }\end{array}$} & 3.0 & & 0.14 & 0.34 & & 1.2 & & 0.18 & & & 0.42 & & & 0.14 & 0.003 & \multirow{3}{*}{ [78] } \\
\hline Mougeotia salina & & 5.1 & & 0.58 & & & 1.7 & & 0.01 & & & 0.05 & & 0.14 & & 0.14 & \\
\hline Nannochloropsis sp. & & 8.6 & & & & & & & & & 6.4 & & & & & & \\
\hline Porphiridium cruentum & \multirow{4}{*}{$\begin{array}{c}\mathrm{mg} / 100 \mathrm{~g} \mathrm{DW} / \mathrm{HPLC} \text { chromatograms } \\
\text { for analysis }\end{array}$} & 167 & & 107 & & & & & & & & & 6.5 & & & & \multirow{4}{*}{ [79] } \\
\hline Isochrysis galbana & & 1760 & & & & & & & 1643 & & & & & 40 & 25 & & \\
\hline Phaeodactylum tricornutum & & 1022 & & & & & & & 913 & & & & & 32 & 44 & & \\
\hline Nannochloropsis gaditana & & 447 & & 10 & & & 337 & & & & & & & & & & \\
\hline Heterochlorella luteoviridis & \multirow{2}{*}{$\begin{array}{c}\mathrm{mg} / \mathrm{g} \text { DW/HPLC-APCI-MS/MS for } \\
\text { analysis }\end{array}$} & 3.4 & 1.8 & 0.08 & & 0.08 & 0.59 & & & & & & & & & & \multirow{2}{*}{ [77] } \\
\hline Dunaliella tertio-lecta & & 3.5 & 1.3 & 0.14 & & & 0.79 & & & & & & & & & & \\
\hline Eustigmatos magnus & \multirow{6}{*}{$\begin{array}{l}\mathrm{mg} / \mathrm{g} \text { DW for total and \% of total } \\
\text { carotenoids for individuals/HPLC } \\
\text { chromatograms for analysis }\end{array}$} & 25 & & 2.6 & 1.9 & 2.1 & 15 & 12 & & & & & & & & & \multirow{6}{*}[80]{} \\
\hline Eustigmatos polyphem & & 14 & & 3.2 & 2.2 & 4.9 & 2.5 & 13 & & & & & & & & & \\
\hline Eustigmatos vischeri & & 2.5 & & 1.9 & 2.6 & 3.5 & 10 & 14 & & & & & & & & & \\
\hline Vischeria helvetica & & 25 & & 1.2 & 2.3 & 4.2 & 12 & 11 & & & & & & & & & \\
\hline Vischeria punctata & & 33 & & 1.7 & 2.4 & 4.7 & 11 & 12 & & & & & & & & & \\
\hline Vischeria stellata & & 55 & & 1.6 & 1.8 & 3.6 & 13 & 7.6 & & & & & & & & & \\
\hline Chlorella pyrenoidosa & $\begin{array}{c}\mu \mathrm{g} / \mathrm{g} \text { DW } / \text { HPLC chromatograms for } \\
\text { analysis }\end{array}$ & & 140376 & 2170 & & & 38 & & & & & 259 & 335 & & & & [81] \\
\hline
\end{tabular}




\section{Industrial Extraction of $\beta$-Carotene from Microalgae}

The production of carotenoids from microalgae includes microalgae culture, harvesting, extraction, and purification. To obtain carotenoids from microalgae, the following steps are usually performed: collection, drying treatment, cell crushing, and extraction. The disruption of the cell wall mechanically is followed by extraction using organic solvents. Other methods include pressure solvent extraction, supercritical/subcritical fluid extraction, in situ extraction, and two-phase extraction, as shown in Figure 1 [29,30]. People have extensively studied the extraction methods to obtain carotenoids from microalgae and have made some progresses. The yield of $\beta$-carotene relied on the total carotenoid mixture obtained and removal of undesired materials.

Figure 2 summarizes the general process of $\beta$-carotene extraction from Dunaliella salina. It starts by growing Dunaliella salina. The growth of Duncaliella salina generally happens in facilities that are designed to operate in a closed circuit using seawater or fresh water. The facility can recirculate the culture medium for 10-14 days. Alternatively, this medium can be continuously collected on a daily basis [87]. After that, the biomass of microalgae is harvested and immediately freeze-dried. The dried matters are disintegrated to release the cellular content (steps 1 to 3 ). Various methods are applied to extract the dried matter, which yield crude extracts containing total carotenoids (step 4), which include $\beta$-carotene, canthaxanthin, astaxanthin, lutein, and others, as shown in Tables 1 and 2. To obtain ingredients enriched in $\beta$-carotene or purified $\beta$-carotene, contaminants have to be removed. Methods include filtration of the solubilized extract with acetone, direct saponification of the extract with calcium hydroxide to remove chlorophyll, or membrane filtration (steps 5) [88-91]. The conventional purification method widely used at present is to enrich $\beta$-carotene by removing chlorophyll directly with calcium hydroxide via saponification. Some scholars modified it by introducing calcium hydroxide saponification and filtration steps before step 4 (solvent extraction), which saponifies microalgae mass for $2-6 \mathrm{~h}$ to remove chlorophyll in an inert gas and at $50-100{ }^{\circ} \mathrm{C}$ [29]. Subsequently, $\beta$-carotene is extracted after the filtration of saponified residues using halogenated hydrocarbon solvents (e.g., methylene chloride) or hydrophobic solvents (e.g., n-hexane or petroleum ether) and recrystallized in methane chloride/methanol [92]. Using a two-phase bioreactor is a good method recently developed to extract $\beta$-carotene from microalgae. It uses biocompatible organic solvent to extract $\beta$-carotene specifically without damaging microalgae cells, and to obtain relatively pure $\beta$-carotene, directly bypassing the steps that are set for the collection of total carotenoids and saponification (steps 2, 3 and 5) [93-95]. A method with advantages of high extraction rate, general, rapid, environmental protection, and low cost is still yet to be developed.

The supercritical carbon dioxide extraction method has been used widely to extract $\beta$-carotenes and carotenoids from microalgae such as Dunaliella salina [91,96], Chlorella vulgaris [91], Scenedesmus almeriensis [32], Synechococcus sp. [97], Nannochloropsis sp. [98], and Spirulina platensis [99]. The ratio of 9-cis- $\beta$-carotene and $\beta$-carotene (all-trans) is used to predict the antioxidant activity of Dunaliella salina extracts [96]. This method has also been used to obtain other compounds such as 25 aroma compounds from sugar cane [100], alkadienes from Botryococcus braunii and $\gamma$-linolenic acid from Arthrospira maxima [91], lipids from Nannochloropsis sp. [98]; flavonoids, VA, and $\alpha$-tocopherol from Spirulina platensis [99]; and indolic derivative and PUFAs from Dunaliella salina [101]. We acknowledge that this may not be a thorough list of supercritical carbon dioxide extraction methods as we have been focused on the studies of biological activities of $\beta$-carotene extracted in this manuscript. 


\section{Schematic procedures of purification of $\beta$-carotene from microalgae}

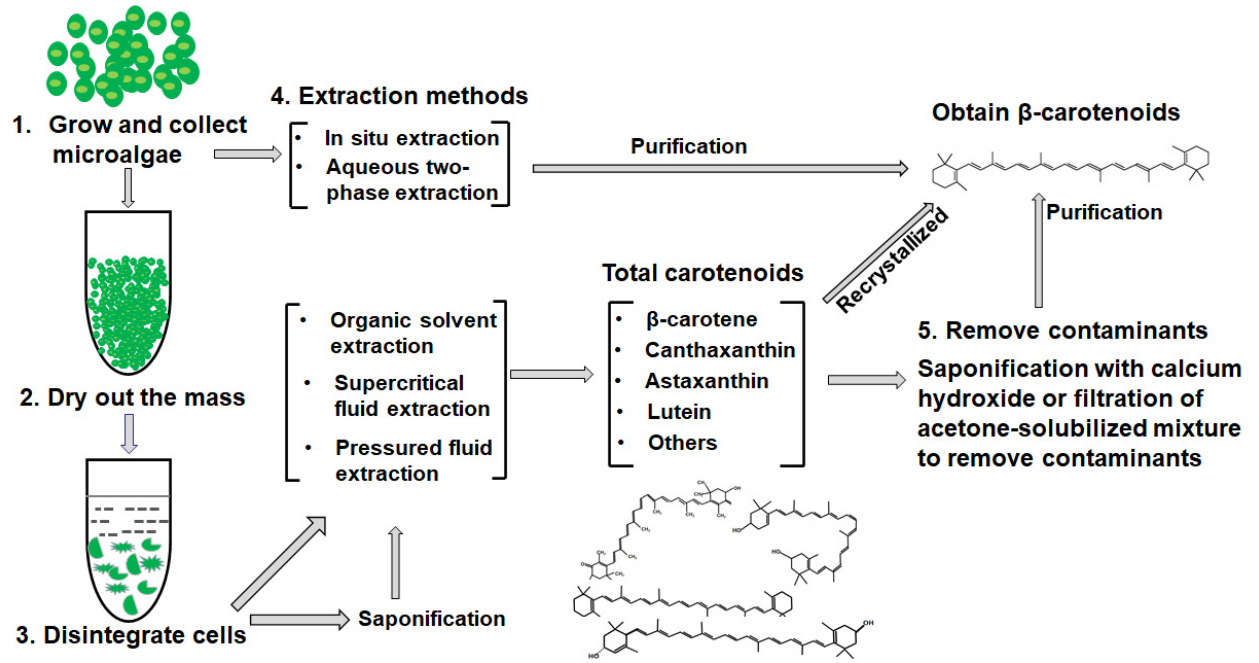

Figure 2. Flow chart of $\beta$-carotene extraction from Dunaliella salina. Microalgae are grown and collected (step 1), dried (step 2), and disintegrated (step 3). Step 4 is to extract total carotenoids using a variety of methods such as organic solvent extraction, pressurized solvent extraction, or supercritical fluid extraction using the similar compatibility principle of organic solvents. The supercritical fluid extraction method selectively recovers carotenoids by controlling the density of supercritical $\mathrm{CO}_{2}$. Due to the high diffusion-coefficient and low viscosity of supercritical $\mathrm{CO}_{2}$, the extraction time is shorter. Alternatively, in situ or aqueous two-phase extraction can be used to enrich or purify $\beta$-carotenoids directly. In addition, saponification and filtration steps can happen before solvent extraction. Step 5 is to remove the chlorophyll component using saponification with calcium hydroxide. After the removal of insoluble matter via filtration, $\beta$-carotene is purified using halogenated hydrocarbon solvents (e.g., methylene chloride) or hydrophobic solvents (e.g., n-hexane or petroleum ether). Alternative, the total carotenoids are solubilized in pure acetone and filtered through a $0.45 \mu \mathrm{m}$ membrane. In situ extraction and two-phase extraction directly extract $\beta$-carotene without collecting, drying, or breaking microalgae cells. In the stress condition, $\beta$-carotene can be selectively extracted continuously by adding biocompatible organic phases to microalgae.

\section{Studies of Bioactivities of $\beta$-Carotene in Microalgae}

Carotenoids have a broad spectrum of biological activities. $\beta$-carotene has antiangiogenesis, anti-cancer, and anti-inflammatory effects. Fucoxanthin has anti-angiogenesis, and heart-protection effects $[102,103]$. As humans cannot synthesize carotenoids, $\beta$-carotene has to come from the diet [104]. $\beta$-carotene has been recognized by the FDA, the European Community, Japan, the $\mathrm{WHO}$, and other international organizations and experts as a precursor of VA, a food additive, and a nutritional supplement [105]. Naturally derived $\beta$-carotene has high biological activity, which can be used in eye diseases, anti-oxidation, anti-aging, cancer prevention, pigmentation in animals, and the enhancement of the animal reproducibility and immune functions [102,106,107]. Streptozotocin-induced diabetic rats have been treated with Dunaliella salina extract prepared through pressurized liquid extraction for up to 3 days [108]. The extract without the analysis of the presence of carotenoids appeared to show beneficial effects but did not improve the glucose levels [108].

To summarize the bioactivity of $\beta$-carotene from microalgae, $\beta$-carotene and microalgae were used as keywords to search the PubMed database and retrieved relevant literature in August 2021. We have limited our search to the studies that have described the methods, analyzed the content for the presence of $\beta$-carotene, and tested the biological activities of the biomass, extracts, or purified product and attributed those activities to $\beta$-carotene. The search resulted in 255 articles, which include 15 articles that used cells and animals in the experiments. Two of them were irrelevant. The remaining 13 articles include 1 drosophila study [3], 8 rat studies [27,28,109-114], 1 cow study [115], 
2 human cell line studies [116,117], and 1 antibacterial activity study [118], as summarized in Table 3. The organic solvent extraction is still the main extraction method that is used in 10 articles $[27,28,109-111,113,114,116-118]$. HPLC is used in majority of these studies $(9 / 13)$ to analyze the extract and determine the presence of $\beta$-carotene and other carotenoids and bioactive compounds $[3,27,109,111,114-118]$. One article used supercritical carbon dioxide extraction to obtain carotenoids, identified the presence of $\beta$-carotene isoforms, analyzed their biological activities, and determined the underlying functional mechanism [3]. The presence of $\beta$-carotenes isoforms is attributed to the extract's ability to extend the drosophila lifespan [3]. Two articles directly used freeze-drying microalgae powder for research $[112,115]$. It appears that all these studies only included total carotenoids from microalgae, which the biological activities can be attributed to. Although the presence of $\beta$-carotene in the extracts or microalgae mass was confirmed, the purified $\beta$-carotene from microalgae has not been used and studied. Therefore, whether the biological activity really can be attributed to $\beta$-carotene is still an open question. The synthetic $\beta$-carotene is all-trans, which is considered less biologically active than the cis- $\beta$-carotenes [119-121]. The naturally extracted $\beta$-carotene contains both all-trans and cis isoforms, which have a higher market prospect and value than the synthetic ones [122,123]. Clearly, future studies using purified $\beta$-carotene from microalgae are anticipated and worth being investigated.

Table 3. Microalgae studies that included extraction methods, identified $\beta$-carotenes, and determined their biological activities in cells or animal models at the same time.

\begin{tabular}{|c|c|c|c|c|c|}
\hline Strains & Materials/Analysis & Isoforms & Subjects Used & Results & Ref. \\
\hline D. salina & $\begin{array}{l}\text { Lyophilized biomass } \\
\text { and extracts using } \\
\text { supercritical } \mathrm{CO}_{2} \text { and } \\
\text { pre-pared by red } \\
\text { light } \\
\text { treatment/HPLC } \\
\text { (UV-vis, 3D image) } \\
\text { chromatograms for } \\
\text { analysis }\end{array}$ & $\begin{array}{l}\text { all-trans and } \\
\text { 9-cis- } \beta \text {-carotene }\end{array}$ & $\begin{array}{c}\text { Male and female } \\
\text { Drosophila } \\
\text { melanogaster Dahomey }\end{array}$ & $\begin{array}{l}\text { Extract extends the } \\
\text { median lifespan, } \\
\text { which is attributed to } \\
\text { the improvement of } \\
\text { mitochondrial } \\
\text { functions by } \\
\text { 9-cis- } \beta \text {-carotene }\end{array}$ & [3] \\
\hline D. salina & $\begin{array}{l}\text { Pressurized fluid } \\
\text { extraction and } \\
\text { hexane/HPLC } \\
\text { chromatograms for } \\
\text { analysis }\end{array}$ & $\beta$-carotene & $\begin{array}{c}\text { Bacteria: P. syringae } \\
\text { pv. tomato } \\
\text { EPS3, B. subtilis ET-1, } \\
\text { P. carotovorum subsp. } \\
\text { carotovorum } \\
\text { DSM30168 }\end{array}$ & $\begin{array}{l}\text { Hexane extract } \\
\text { inhibits bacterial } \\
\text { growth, and re-duces } \\
\text { speck spot diseases } \\
\text { in tomato plants. }\end{array}$ & [118] \\
\hline $\begin{array}{l}\text { S. platensis and } \\
\text { D. salina }\end{array}$ & $\begin{array}{l}\text { Hexane:isopropyl } \\
\text { alcohol (1:1 vol/vol) } \\
\text { extraction/HPLC } \\
\text { chromatograms for } \\
\text { analysis }\end{array}$ & $\begin{array}{l}\beta \text {-carotene in } \\
\text { S. plantensis; } \\
\text { carotenoids and } \\
\text { xanthophyl in } \\
\text { D. salina }\end{array}$ & $\begin{array}{l}\text { Male and female } \\
\text { Wistar rats }\end{array}$ & $\begin{array}{l}\text { The extract of } \\
\text { D. Salina has better } \\
\text { hepato-protective } \\
\text { activity than that of } \\
\text { S. plantensis. }\end{array}$ & [27] \\
\hline D. Salina & $\begin{array}{c}\text { Hexane:ethyl acetate } \\
(80: 20) \\
\text { extraction/HPLC } \\
\text { chromatograms and } \\
\text { GC/MS for analysis }\end{array}$ & $\begin{array}{c}\beta \text {-carotene }(15.2 \% \text { of } \\
\text { the algal extract) }\end{array}$ & $\begin{array}{l}\text { Adult male albino } \\
\text { Wistar rats }\end{array}$ & $\begin{array}{c}\text { D. salina extract } \\
\text { protects against } \\
\text { TAA-induced hepatic } \\
\text { fibrosis in rats. }\end{array}$ & [109] \\
\hline S. platensis & $\begin{array}{l}\text { Spray-dried } \\
\text { mass/HPLC for } \\
\text { analysis }\end{array}$ & $\begin{array}{c}\text { Diet with } 5 \% \\
\text { spray-dried } \\
\text { S. platensis that } \\
\text { contain } \beta \text {-carotene }\end{array}$ & Cows & $\begin{array}{l}\text { Supplementation of } \\
\text { S. platensis leads to } \\
\text { higher } \beta \text {-carotene } \\
\text { content in the milk } \\
\text { than the control } \\
\text { group. }\end{array}$ & {$[115]$} \\
\hline
\end{tabular}


Table 3. Cont.

\begin{tabular}{|c|c|c|c|c|c|}
\hline Strains & Materials/Analysis & Isoforms & Subjects Used & Results & Ref. \\
\hline D. Salina & $\begin{array}{c}\text { Hexane: ethyl acetate } \\
(80: 20) \\
\text { extraction/Repeated } \\
\text { chromatographic } \\
\text { analysis }\end{array}$ & Carotenoids & Male Wistar rats & $\begin{array}{l}\text { Extracted carotenoids } \\
\text { protects age-induced } \\
\text { hepatic steatosis via } \\
\text { regulating redox } \\
\text { status, inflammation, } \\
\text { and apoptosis in } \\
\text { senescence rats. }\end{array}$ & [110] \\
\hline D. Salina & $\begin{array}{l}\text { n-Hexane: isopropyl } \\
\text { alcohol (1:1) } \\
\text { extraction/HPLC for } \\
\text { analysis }\end{array}$ & Carotenoids & Wistar rats & $\begin{array}{l}\text { Extracted carotenoids } \\
\text { have better } \\
\text { antioxidant activity } \\
\text { than synthetic } \\
\text { carotene in rat liver } \\
\text { homogenates. }\end{array}$ & [111] \\
\hline D. Salina & $\begin{array}{c}\text { Lyophilized } \\
\text { pellets / Absorption } \\
\text { spectroscopy at } 443 \\
\text { and } 475 \text { nm to } \\
\text { confirm the presence } \\
\beta \text {-carotene isomers }\end{array}$ & $\begin{array}{c}\text { 9-cis- and } \\
\text { 11-cis- } \beta \text {-carotene }\end{array}$ & Male Wistar rats & $\begin{array}{l}\text { 9-cis- } \beta \text {-carotene in } \\
\text { algae pellets might } \\
\text { have anti-cancer } \\
\text { activity. }\end{array}$ & [112] \\
\hline $\begin{array}{l}\text { S. platensis, } \\
\text { H. pluvialis, and } \\
\text { B. braunii }\end{array}$ & $\begin{array}{l}\text { Extracted with } \\
\text { acetone, chloroform, } \\
\text { methanol, and } \\
\text { petroleum ether } \\
\text { separately, and } \\
\text { pooled/MS for } \\
\text { detection }\end{array}$ & $\begin{array}{l}\text { Carotenoids and } \\
\text { chlorophyll }\end{array}$ & Male Wistar rats & $\begin{array}{l}\text { The treated rats have } \\
\text { higher antioxidant } \\
\text { enzymes, and } \\
\text { activities in the blood } \\
\text { and liver than the } \\
\text { controls. }\end{array}$ & [28] \\
\hline $\begin{array}{l}\text { P. lutheri, P. palmata, } \\
\text { P. dioica and C. crispus }\end{array}$ & $\begin{array}{c}\text { Extracted with } \\
\text { methanol:chloroform } \\
1: 1(v / v) \text {, then water } \\
\text { added to collect the } \\
\text { organic phase/HPLC } \\
\text { chromatograms for } \\
\text { analysis }\end{array}$ & $\begin{array}{l}\text { Extracts have } 34-42 \% \\
\text { total fatty acids as n-3 } \\
\text { PUFA and 5-7\% as } \\
\text { pigments, including } \\
\text { chlorophyll a, } \\
\beta \text {-carotene and } \\
\text { fucoxanthin. }\end{array}$ & $\begin{array}{c}\text { Human THP-1 } \\
\text { macrophage cells }\end{array}$ & $\begin{array}{l}\text { Crude extracts inhibit } \\
\text { lipopolysaccharide- } \\
\text { induced } \\
\text { inflammatory } \\
\text { responses in human } \\
\text { THP-1 macrophage } \\
\text { cells. }\end{array}$ & [116] \\
\hline
\end{tabular}

\begin{tabular}{|c|c|c|c|c|c|}
\hline S. platensis & $\begin{array}{l}\text { Lyophilized algae } \\
\text { were extracted with } \\
\text { ethyl ether and then } \\
\text { methanol/Absorption } \\
\text { spectroscopy for } \\
\text { analysis }\end{array}$ & $\begin{array}{c}\text { Extracts (per liter } \\
\text { solvent) have } 96.3 \mathrm{mg} \\
\text { phenolic, } 18 \mathrm{mg} \\
\text { tocopherol and } \\
27.5 \mathrm{mg} \beta \text {-carotene. }\end{array}$ & Male Wistar rats & $\begin{array}{l}\text { Extracts show } \\
\text { antioxidant activity } \\
\text { both in vitro and } \\
\text { in vivo. }\end{array}$ & [113] \\
\hline B. braunii (LB 572) & $\begin{array}{c}\text { Acetone } \\
\text { extract/HPLC } \\
\text { chromatograms for } \\
\text { analysis }\end{array}$ & $\begin{array}{l}\text { The extract has } \\
4.7-7.6 \mu \mathrm{g} / \mathrm{mg} \\
\text { carotenoids and } \\
11-12.7 \mu \mathrm{g} / \mathrm{mg} \\
\text { polyphenols. }\end{array}$ & Male Wistar rats & $\begin{array}{l}\text { The extract acts as } \\
\text { antioxidant to } \\
\text { reduces free radicals } \\
\text { and hydroxy radicals } \\
\text { and prevent lipid } \\
\text { peroxidation. }\end{array}$ & [114] \\
\hline
\end{tabular}

$\begin{array}{cc}\text { Characiopsis } & \text { Dichloromethane: } \\ \text { aquilonaris, } & \text { methanol }(1: 1, v / v) \\ \text { Chlorobotrys gloeothece } & \text { extraction/HPLC } \\ \text { and Chlorobotrys } & \text { chromatograms for } \\ \text { regularis } & \text { analysis }\end{array}$

Extracts (mg/g DW)

contain respectively

chlorophyll a (18.4,

$7.3,17.5)$, carotenoids

$(2.3,1.2,1.4)$ and

phenolic acid $(6.2,3.2$,
Normal human Extracts from these

dermal fibroblasts microalgae show

antioxidant activities.

Note: B. braunii, Botryococcusbraunii; C. crispus, Chondrus crispus; DW, dried weight; D. salina, Dunaliella salina; HPLC, high-performance liquid chromatography; GC, gas chromatography; H. pluvialis; Haematococcuspluvialis; P. lutheri, Pavlova lutheri; MS, mass spectrometry; S. platensis, Spirulina platensis; TAA, thioacetamide.

In the cell and animal studies, extracts from microalgae extended the lifespan of drosophila via improvement of mitochondrial functions [3], protected the liver functions in rats via the regulation of inflammation and redox status $[27,109,110]$, increased the antioxidative activities in rats $[28,111,113,114]$ and in human dermal fibroblast cells [117], and raised the $\beta$-carotene content in cow's milk [115]. In addition, extracts also being shown to inhibit the growth of pathogenic bacteria on tomato [118]. Some of the studies reported the presence of specific isoforms of $\beta$-carotene $[3,112], \beta$-carotene $[27,110,113,115,116,118]$, 
or total carotenoids with or without other components such as PUFA or phenolic acid [27, $28,110,111,114,117]$. The microalgae sources that $\beta$-carotene, total carotenoids, and biomass are derived from are D. salina [3,27,109-112,118]; S. platensis [27,28,113,115]; H. pluvialis [28]; B. braunii [28,114]; P. lutheri, P. palmata, P. dioica, and C. crispus [116]; and Characiopsis aquilonaris, Chlorobotrys gloeothece, and Chlorobotrys regularis [117].

\section{Conclusions and Future Perspectives}

As carotenoids have a variety of biological activities, $\beta$-carotene is widely used as a bioactive compound in the biomedical field. Currently, $\beta$-carotene products on the market are mainly synthetic ones, whereas products extracted from the natural sources only occupy a small fraction. Given the fact that the cis- $\beta$-carotene isoforms extracted from natural sources are more potent than the synthetic all-trans- $\beta$-carotene, we can anticipate that microalgae will be used to extract and purify the naturally derived cis- $\beta$-carotenes on a large scale in the future. To improve the extraction methods, some new technologies such as supercritical carbon dioxide extraction have been developed. The supercritical carbon dioxide extraction method has been used widely to extract carotenoids and other bioactive compounds. It is only a matter of time before more extracts derived from the supercritical carbon dioxide extraction methods will be used in other biological studies using animals or cells in the future. Each extraction method is unique and has a different extraction efficiency. They all have pros and cons. More practical and more effective extraction methods are anticipated in the future.

The extracts of different microalgae sources contain significant amounts of other carotenoids in addition to $\beta$-carotene. A variety of methods are applied to show that the extracts contain $\beta$-carotene and have positive impacts on animals and cells. These beneficial effects include antioxidant, anti-inflammation, antibacterial, promoting milk production, and increases in lifespan. However, there appears to be a lack of studies using purified $\beta$-carotenes to test their bioactivities in cells and animal models. Therefore, whether these positive effects are due to $\beta$-carotene or a mixture of bioactive compounds including $\beta$-carotene remains to be revealed. In addition, whether $\beta$-carotene should be used alone or in combination with other carotenoids to maximize its bioactivities is another open question waiting for answers. Finally, more cellular, animals, and clinical studies are also expected to advance our understanding of the underlying mechanisms by which $\beta$-carotene exerts beneficials effects on human and animal health. All these deserve to be explored in the future. Nevertheless, $\beta$-carotene derived from microalgae will play an important role in the process.

Author Contributions: Conceptualization, J.W. and G.C.; PubMed search, J.W., X.H. (Xinge Hu), J.C. and T.W.; writing-review and editing, J.W., X.H. (Xinge Hu), J.C., T.W., X.H. (Xianju Huang) and G.C. All authors have read and agreed to the published version of the manuscript.

Funding: This research received no external funding.

Institutional Review Board Statement: Not applicable.

Informed Consent Statement: Not applicable.

Data Availability Statement: Not applicable.

Acknowledgments: The authors would like to thank the South-central University for Nationalities for the scholarship to Jing Wang, and the Department of Nutrition at the University of Tennessee, Knoxville for the assistantships to Xinge Hu and Tiannan Wang.

Conflicts of Interest: The authors declare no conflict of interest.

\section{References}

1. Khan, M.I.; Shin, J.H.; Kim, J.D. The promising future of microalgae: Current status, challenges, and optimization of a sustainable and renewable industry for biofuels, feed, and other products. Microb. Cell Factories 2018, 17, 36. [CrossRef] [PubMed]

2. Barsanti, L.; Coltelli, P.; Evangelista, V.; Frassanito, A.M.; Passarelli, V.; Vesentini, N.; Gualtieri, P. Oddities and Curiosities in the Algal World. In Algal Toxins: Nature, Occurrence, Effect and Detection; Springer: Dordrecht, The Netherlands, 2008. 
3. Weinrich, T.; Xu, Y.; Wosu, C.; Harvey, P.J.; Jeffery, G. Mitochondrial Function, Mobility and Lifespan Are Improved in Drosophila melanogaster by Extracts of 9-cis- $\beta$-Carotene from Dunaliella salina. Mar. Drugs 2019, 17, 279. [CrossRef]

4. Bule, M.H.; Ahmed, I.; Maqbool, F.; Bilal, M.; Iqbal, H.M.N. Microalgae as a source of high-value bioactive compounds. Front. Biosci. 2018, 10, 197-216.

5. Talero, E.; García-Mauriño, S.; Ávila-Román, J.; Rodríguez-Luna, A.; Alcaide, A.; Motilva, V. Bioactive Compounds Isolated from Microalgae in Chronic Inflammation and Cancer. Mar. Drugs 2015, 13, 6152-6209. [CrossRef] [PubMed]

6. Domínguez, H. 1-Algae as a source of biologically active ingredients for the formulation of functional foods and nutraceuticals. In Functional Ingredients from Algae for Foods and Nutraceuticals; Domínguez, H., Ed.; Woodhead Publishing: Cambridge, UK, 2013; pp. 1-19.

7. Gong, M.; Bassi, A. Carotenoids from microalgae: A review of recent developments. Biotechnol. Adv. 2016, 34, 1396-1412. [CrossRef] [PubMed]

8. Sun, X.M.; Ren, L.J.; Zhao, Q.Y.; Ji, X.J.; Huang, H. Microalgae for the production of lipid and carotenoids: A review with focus on stress regulation and adaptation. Biotechnol. Biofuels 2018, 11, 272. [CrossRef] [PubMed]

9. Cezare-Gomes, E.A.; Mejia-da-Silva, L.D.C.; Pérez-Mora, L.S.; Matsudo, M.C.; Ferreira-Camargo, L.S.; Singh, A.K.; de Carvalho, J.C.M. Potential of Microalgae Carotenoids for Industrial Application. Appl. Biochem. Biotechnol. 2019, 188, 602-634. [CrossRef]

10. Zhang, X.; Rong, J.; Chen, H.; He, C.; Wang, Q. Current Status and Outlook in the Application of Microalgae in Biodiesel Production and Environmental Protection. Front. Energy Res. 2014, 2, 32. [CrossRef]

11. Ugwu, C.U.; Aoyagi, H.; Uchiyama, H. Photobioreactors for mass cultivation of algae. Bioresour. Technol. 2008, 99, 4021-4028. [CrossRef]

12. Xu, Z.; Jiang, Y.; Ji, J.; Forsberg, E.; Li, Y.; He, S. Classification, identification, and growth stage estimation of microalgae based on transmission hyperspectral microscopic imaging and machine learning. Opt. Express 2020, 28, 30686-30700. [CrossRef]

13. Sanghvi, A.M.; Lo, Y.M. Present and potential industrial applications of macro- and microalgae. Recent Pat. Food Nutr. Agric. 2010, 2, 187-194. [CrossRef] [PubMed]

14. Kratzer, R.; Murkovic, M. Food Ingredients and Nutraceuticals from Microalgae: Main Product Classes and Biotechnological Production. Foods 2021, 10, 1626. [CrossRef] [PubMed]

15. Vieira, M.V.; Pastrana, L.M.; Fuciños, P. Microalgae Encapsulation Systems for Food, Pharmaceutical and Cosmetics Applications. Mar. Drugs 2020, 18, 644. [CrossRef]

16. Barkia, I.; Saari, N.; Manning, S.R. Microalgae for High-Value Products Towards Human Health and Nutrition. Mar. Drugs 2019, 17, 304. [CrossRef] [PubMed]

17. Ljubic, A.; Jacobsen, C.; Holdt, S.L.; Jakobsen, J. Microalgae Nannochloropsis oceanica as a future new natural source of vitamin D(3). Food Chem. 2020, 320, 126627. [CrossRef] [PubMed]

18. Del Mondo, A.; Smerilli, A.; Sané, E.; Sansone, C.; Brunet, C. Challenging microalgal vitamins for human health. Microb. Cell Factories 2020, 19, 201. [CrossRef]

19. Lafarga, T.; Fernández-Sevilla, J.M.; González-López, C.; Acién-Fernández, F.G. Spirulina for the food and functional food industries. Food Res. Int. 2020, 137, 109356. [CrossRef]

20. Foong, L.C.; Loh, C.W.L.; Ng, H.S.; Lan, J.C. Recent development in the production strategies of microbial carotenoids. World J. Microbiol. Biotechnol. 2021, 37, 12. [CrossRef]

21. Tanguy, G.; Legat, A.; Gonçalves, O.; Marchal, L.; Schoefs, B. Selection of Culture Conditions and Cell Morphology for Biocompatible Extraction of $\beta$-Carotene from Dunaliella salina. Mar. Drugs 2021, 19, 648. [CrossRef]

22. Chen, W.; Chen, G. The Roles of Vitamin A in the Regulation of Carbohydrate, Lipid, and Protein Metabolism. J. Clin. Med. 2014, 3, 453-479. [CrossRef]

23. Marcelino, G.; Machate, D.J.; Freitas, K.d.C.; Hiane, P.A.; Maldonade, I.R.; Pott, A.; Asato, M.A.; Candido, C.J.; Guimarães, R.d.C.A. $\beta$-Carotene: Preventive Role for Type 2 Diabetes Mellitus and Obesity: A Review. Molecules 2020, 25, 5803. [CrossRef] [PubMed]

24. Riccio, G.; Lauritano, C. Microalgae with Immunomodulatory Activities. Mar. Drugs 2019, 18, 2. [CrossRef] [PubMed]

25. Martínez Andrade, K.A.; Lauritano, C.; Romano, G.; Ianora, A. Marine Microalgae with Anti-Cancer Properties. Mar. Drugs 2018, 16, 165. [CrossRef] [PubMed]

26. Ambati, R.R.; Gogisetty, D.; Aswathanarayana, R.G.; Ravi, S.; Bikkina, P.N.; Bo, L.; Yuepeng, S. Industrial potential of carotenoid pigments from microalgae: Current trends and future prospects. Crit. Rev. Food Sci. Nutr. 2019, 59, 1880-1902. [CrossRef]

27. Murthy, K.N.; Rajesha, J.; Swamy, M.M.; Ravishankar, G.A. Comparative evaluation of hepatoprotective activity of carotenoids of microalgae. J. Med. Food 2005, 8, 523-528. [CrossRef]

28. Ranga Rao, A.; Raghunath Reddy, R.L.; Baskaran, V.; Sarada, R.; Ravishankar, G.A. Characterization of microalgal carotenoids by mass spectrometry and their bioavailability and antioxidant properties elucidated in rat model. J. Agric. Food Chem. 2010, 58, 8553-8559. [CrossRef]

29. Rammuni, M.N.; Ariyadasa, T.U.; Nimarshana, P.H.V.; Attalage, R.A. Comparative assessment on the extraction of carotenoids from microalgal sources: Astaxanthin from H. pluvialis and $\beta$-carotene from D. salina. Food Chem. 2019, 277, 128-134. [CrossRef]

30. Poojary, M.M.; Barba, F.J.; Aliakbarian, B.; Donsi, F.; Pataro, G.; Dias, D.A.; Juliano, P. Innovative Alternative Technologies to Extract Carotenoids from Microalgae and Seaweeds. Mar. Drugs 2016, 14, 214. [CrossRef] 
31. Prado, M.J.; Veggi, C.P.; Meireles, A.A.M. Extraction Methods for Obtaining Carotenoids from Vegetables-Review. Curr. Anal. Chem. 2014, 10, 29-66. [CrossRef]

32. Macías-Sánchez, M.D.; Fernandez-Sevilla, J.M.; Fernández, F.G.A.; García, M.C.C.; Grima, E.M. Supercritical fluid extraction of carotenoids from Scenedesmus almeriensis. Food Chem. 2010, 123, 928-935. [CrossRef]

33. Institute of Medicine Panel on M. Dietary Reference Intakes for Vitamin A, Vitamin K, Arsenic, Boron, Chromium, Copper, Iodine, Iron, Manganese, Molybdenum, Nickel, Silicon, Vanadium, and Zinc; National Academies Press (US): Washington, DC, USA, 2001.

34. O'Byrne, S.M.; Blaner, W.S. Retinol and retinyl esters: Biochemistry and physiology. J. Lipid Res. 2013, 54, 1731-1743. [CrossRef] [PubMed]

35. Harrison, E.H. Mechanisms involved in the intestinal absorption of dietary vitamin A and provitamin A carotenoids. Biochim. Biophys. Acta 2012, 1821, 70-77. [CrossRef] [PubMed]

36. Tanumihardjo, S.A. Assessing vitamin A status: Past, present and future. J. Nutr. 2004, 134, 290s-293s. [CrossRef] [PubMed]

37. Alapatt, P.; Guo, F.; Komanetsky, S.M.; Wang, S.; Cai, J.; Sargsyan, A.; Rodríguez Díaz, E.; Bacon, B.T.; Aryal, P.; Graham, T.E. Liver retinol transporter and receptor for serum retinol-binding protein (RBP4). J. Biol. Chem. 2013, 288, 1250-1265. [CrossRef] [PubMed]

38. Folli, C.; Calderone, V.; Ottonello, S.; Bolchi, A.; Zanotti, G.; Stoppini, M.; Berni, R. Identification, retinoid binding, and x-ray analysis of a human retinol-binding protein. Proc. Natl. Acad. Sci. USA 2001, 98, 3710-3715. [CrossRef] [PubMed]

39. Shete, V.; Quadro, L. Mammalian metabolism of $\beta$-carotene: Gaps in knowledge. Nutrients 2013, 5, 4849-4868. [CrossRef]

40. During, A.; Smith, M.K.; Piper, J.B.; Smith, J.C. $\beta$-Carotene 15,15'-Dioxygenase activity in human tissues and cells: Evidence of an iron dependency. J. Nutr. Biochem. 2001, 12, 640-647. [CrossRef]

41. Dawson, M.I. The importance of vitamin A in nutrition. Curr. Pharm. Des. 2000, 6, 311-325. [CrossRef]

42. Patias, L.D.; Fernandes, A.S.; Petry, F.C.; Mercadante, A.Z.; Jacob-Lopes, E.; Zepka, L.Q. Carotenoid profile of three microalgae/cyanobacteria species with peroxyl radical scavenger capacity. Food Res. Int. 2017, 100, 260-266. [CrossRef]

43. Von Lintig, J. Provitamin A metabolism and functions in mammalian biology. Am. J. Clin. Nutr. 2012, 96, 1234s-1244s. [CrossRef]

44. Eroglu, A.; Harrison, E.H. Carotenoid metabolism in mammals, including man: Formation, occurrence, and function of apocarotenoids. J. Lipid Res. 2013, 54, 1719-1730. [CrossRef] [PubMed]

45. Van Bennekum, A.; Werder, M.; Thuahnai, S.T.; Han, C.H.; Duong, P.; Williams, D.L.; Wettstein, P.; Schulthess, G.; Phillips, M.C.; Hauser, H. Class B scavenger receptor-mediated intestinal absorption of dietary beta-carotene and cholesterol. Biochemistry 2005, 44, 4517-4525. [CrossRef] [PubMed]

46. Kiefer, C.; Hessel, S.; Lampert, J.M.; Vogt, K.; Lederer, M.O.; Breithaupt, D.E.; von Lintig, J. Identification and characterization of a mammalian enzyme catalyzing the asymmetric oxidative cleavage of provitamin A. J. Biol. Chem. 2001, 276, 14110-14116. [CrossRef] [PubMed]

47. Harrison, E.H.; Quadro, L. Apocarotenoids: Emerging Roles in Mammals. Annu. Rev. Nutr. 2018, 38, 153-172. [CrossRef] [PubMed]

48. Harrison, E.H.; Kopec, R.E. Enzymology of vertebrate carotenoid oxygenases. Biochim. Biophys. Acta Mol. Cell Biol. Lipids 2020, 1865, 158653.

49. Amengual, J.; Widjaja-Adhi, M.A.K.; Rodriguez-Santiago, S.; Hessel, S.; Golczak, M.; Palczewski, K.; von Lintig, J. Two carotenoid oxygenases contribute to mammalian provitamin A metabolism. J. Biol. Chem. 2013, 288, 34081-34096. [CrossRef] [PubMed]

50. Gómez-Zorita, S.; Trepiana, J.; González-Arceo, M.; Aguirre, L.; Milton-Laskibar, I.; González, M.; Eseberri, I.; Fernández-Quintela, A.; Portillo, M.P. Anti-Obesity Effects of Microalgae. Int. J. Mol. Sci. 2019, $21,41$.

51. Zarezadeh, M.; Faghfouri, A.H.; Radkhah, N.; Foroumandi, E.; Khorshidi, M.; Rasouli, A.; Zarei, M. Mohammadzadeh Honarvar N, Hazhir Karzar N, and Ebrahimi Mamaghani M, Spirulina supplementation and anthropometric indices: A systematic review and meta-analysis of controlled clinical trials. Phytother. Res. 2021, 35, 577-586. [CrossRef]

52. Moradi, S.; Ziaei, R.; Foshati, S.; Mohammadi, H.; Nachvak, S.M.; Rouhani, M.H. Effects of Spirulina supplementation on obesity: A systematic review and meta-analysis of randomized clinical trials. Complement. Ther. Med. 2019, 47, 102211. [CrossRef]

53. Finamore, A.; Palmery, M.; Bensehaila, S.; Peluso, I. Antioxidant, Immunomodulating, and Microbial-Modulating Activities of the Sustainable and Ecofriendly Spirulina. Oxid. Med. Cell Longev. 2017, 2017, 3247528. [CrossRef]

54. Raposo, M.F.; de Morais, A.M.; de Morais, R.M. Carotenoids from Marine Microalgae: A Valuable Natural Source for the Prevention of Chronic Diseases. Mar. Drugs 2015, 13, 5128-5155. [CrossRef] [PubMed]

55. Stahl, W.; Sies, H. $\beta$-Carotene and other carotenoids in protection from sunlight. Am. J. Clin. Nutr. 2012, 96, 1179s-1184s. [CrossRef] [PubMed]

56. Kammeyer, A.; Luiten, R.M. Oxidation events and skin aging. Ageing Res. Rev. 2015, 21, 16-29. [CrossRef] [PubMed]

57. Suganuma, K.; Nakajima, H.; Ohtsuki, M.; Imokawa, G. Astaxanthin attenuates the UVA-induced up-regulation of matrixmetalloproteinase-1 and skin fibroblast elastase in human dermal fibroblasts. J. Dermatol. Sci. 2010, 58, 136-142. [CrossRef] [PubMed]

58. Meephansan, J.; Rungjang, A.; Yingmema, W.; Deenonpoe, R.; Ponnikorn, S. Effect of astaxanthin on cutaneous wound healing Clin. Cosmet Investig. Dermatol. 2017, 10, 259-265. [CrossRef]

59. Riley, W.W.; Nickerson, J.G.; Burton, G.W. Effect of oxidized $\beta$-carotene on the growth and feed efficiency of broilers. Poult. Sci. 2021, 100, 101088. [CrossRef] 
60. Morocho-Jácome, A.L.; Ruscinc, N.; Martinez, R.M.; de Carvalho, J.C.M.; Santos de Almeida, T.; Rosado, C.; Costa, J.G.; Velasco, M.V.R.; Baby, A.R. (Bio)Technological aspects of microalgae pigments for cosmetics. Appl. Microbiol. Biotechnol. 2020, 104, 9513-9522. [CrossRef]

61. Baker, R.; Günther, C. The role of carotenoids in consumer choice and the likely benefits from their inclusion into products for human consumption. Trends Food Sci. Technol. 2004, 15, 484-488. [CrossRef]

62. Borowitzka, L.J.; Borowitzka, M.A. $\beta$-Carotene (Provitamin A) Production with Algae. In Biotechnology of Vitamins, Pigments and Growth Factors; Vandamme, E.J., Ed.; Springer: Dordrecht, The Netherlands, 1989; pp. 15-26.

63. Bhosale, P.; Bernstein, P.S. Microbial xanthophylls. Appl. Microbiol. Biotechnol. 2005, 68, 445-455. [CrossRef]

64. Moeller, S.M.; Jacques, P.F.; Blumberg, J.B. The potential role of dietary xanthophylls in cataract and age-related macular degeneration. J. Am. Coll. Nutr. 2000, 19, 522s-527s. [CrossRef]

65. Lin, J.H.; Lee, D.J.; Chang, J.S. Lutein production from biomass: Marigold flowers versus microalgae. Bioresour. Technol. 2015, 184, 421-428. [CrossRef] [PubMed]

66. Ou, Y.; Lin, L.; Yang, X.; Pan, Q.; Cheng, X. Antidiabetic potential of phycocyanin: Effects on KKAy mice. Pharm. Biol. 2013, 51, 539-544. [CrossRef] [PubMed]

67. Chen, J.C.; Liu, K.S.; Yang, T.J.; Hwang, J.H.; Chan, Y.C.; Lee, I.T. Spirulina and C-phycocyanin reduce cytotoxicity and inflammation-related genes expression of microglial cells. Nutr. Neurosci. 2012, 15, 252-256. [CrossRef] [PubMed]

68. Reddy, M.C.; Subhashini, J.; Mahipal, S.V.; Bhat, V.B.; Srinivas Reddy, P.; Kiranmai, G.; Madyastha, K.M.; Reddanna, P. CPhycocyanin, a selective cyclooxygenase-2 inhibitor, induces apoptosis in lipopolysaccharide-stimulated RAW 264.7 macrophages. Biochem. Biophys. Res. Commun. 2003, 304, 385-392. [CrossRef]

69. Santos, H.O.; Price, J.C.; Bueno, A.A. Beyond Fish Oil Supplementation: The Effects of Alternative Plant Sources of Omega-3 Polyunsaturated Fatty Acids upon Lipid Indexes and Cardiometabolic Biomarkers-An Overview. Nutrients 2020, $12,3159$. [CrossRef] [PubMed]

70. Khozin-Goldberg, I.; Iskandarov, U.; Cohen, Z. LC-PUFA from photosynthetic microalgae: Occurrence, biosynthesis, and prospects in biotechnology. Appl. Microbiol. Biotechnol. 2011, 91, 905-915. [CrossRef] [PubMed]

71. Martins, D.A.; Custódio, L.; Barreira, L.; Pereira, H.; Ben-Hamadou, R.; Varela, J.; Abu-Salah, K.M. Alternative sources of n-3 long-chain polyunsaturated fatty acids in marine microalgae. Mar. Drugs 2013, 11, 2259-2281. [CrossRef]

72. Aasen, A.J.; Eimhjellen, K.E.; Liaaen-Jensen, S. An extreme source of beta-carotene. Acta Chem. Scand. 1969, 23, 2544-2545. [CrossRef]

73. MiL'Ko, F. The effect of various environmental factors upon pigments formation in the alga Dunaliella salina. Mikrobiologiya 1963, 32, 299-307.

74. Koyande, A.K.; Chew, K.W.; Rambabu, K.; Tao, Y.; Chu, D.-T.; Show, P.-L. Microalgae: A potential alternative to health supplementation for humans. Food Sci. Hum. Wellness 2019, 8, 16-24. [CrossRef]

75. Fernandes, A.S.; Petry, F.C.; Mercadante, A.Z.; Jacob-Lopes, E.; Zepka, L.Q. HPLC-PDA-MS/MS as a strategy to characterize and quantify natural pigments from microalgae. Curr. Res. Food Sci. 2020, 3, 100-112. [CrossRef] [PubMed]

76. Soares, A.T.; da Costa, D.C.; Vieira, A.A.H. Antoniosi Filho NR, Analysis of major carotenoids and fatty acid composition of freshwater microalgae. Heliyon 2019, 5, e01529. [CrossRef] [PubMed]

77. Diprat, A.B.; Menegol, T.; Boelter, J.F.; Zmozinski, A. Rodrigues Vale MG, Rodrigues E, Rech R, Chemical composition of microalgae Heterochlorella luteoviridis and Dunaliella tertiolecta with emphasis on carotenoids. J. Sci. Food Agric. 2017, 97, 3463-3468. [CrossRef] [PubMed]

78. Zanella, L.; Vianello, F. Microalgae of the genus Nannochloropsis: Chemical composition and functional implications for human nutrition. J. Funct. Foods 2020, 68, 103919. [CrossRef]

79. Di Lena, G.; Casini, I.; Lucarini, M.; Lombardi-Boccia, G. Carotenoid profiling of five microalgae species from large-scale production. Food Res. Int. 2019, 120, 810-818. [CrossRef]

80. Li, Z.; Sun, M.; Li, Q.; Li, A.; Zhang, C. Profiling of carotenoids in six microalgae (Eustigmatophyceae) and assessment of their $\beta$-carotene productions in bubble column photobioreactor. Biotechnol. Lett. 2012, 34, 2049-2053. [CrossRef]

81. Inbaraj, B.S.; Chien, J.T.; Chen, B.H. Improved high performance liquid chromatographic method for determination of carotenoids in the microalga Chlorella pyrenoidosa. J. Chromatogr. A 2006, 1102, 193-199. [CrossRef]

82. Moulton, T.P.; Borowitzka, L.J.; Vincent, D.J. The mass culture of Dunaliella salina for $\beta$-carotene: From pilot plant to production plant. Hydrobiologia 1987, 151, 99-105. [CrossRef]

83. Přibyl, P.; Cepák, V.; Zachleder, V. Oil Overproduction by Means of Microalgae. In Algal Biorefineries: Volume 1: Cultivation of Cells and Products; Bajpai, R., Prokop, A., Zappi, M., Eds.; Springer: Dordrecht, The Netherlands, 2014; pp. $241-273$.

84. Marino, T.; Casella, P.; Sangiorgio, P.; Verardi, A.; Ferraro, A.; Hristoforou, E.; Molino, A.; Musmarra, D. Natural Beta-carotene: A Microalgae Derivate for Nutraceutical Applications. Chem. Eng. Trans. 2021, 79, 103-108.

85. Novoveská, L.; Ross, M.E.; Stanley, M.S.; Pradelles, R.; Wasiolek, V.; Sassi, J.-F. Microalgal Carotenoids: A Review of Production, Current Markets, Regulations, and Future Direction. Mar. Drugs 2019, 17, 640. [CrossRef]

86. Saefurahman, G.; Turner, S.; Basharat, S.; O’Regan, F.J.; Garcia, R.H.; Beatty, S.; Nolan, J.M. Macular Carotenoids Conference 2015 Cambridge, UK-8-10 July 2015. Eur. J. Ophthalmol. 2015, 25, e65-e66. 
87. Cerón-García, M.C.; González-López, C.V.; Camacho-Rodríguez, J.; López-Rosales, L.; García-Camacho, F.; Molina-Grima, E. Maximizing carotenoid extraction from microalgae used as food additives and determined by liquid chromatography (HPLC). Food Chem. 2018, 257, 316-324. [CrossRef]

88. Pour Hosseini, S.R.; Tavakoli, O. Sarrafzadeh MH, Experimental optimization of SC-CO2 extraction of carotenoids from Dunaliella salina. J. Supercrit. Fluids 2017, 121, 89-95. [CrossRef]

89. Abu-Rezq, T.S.; Al-Hooti, S.; Jacob, D.; Al-Shamali, M.; Ahmed, A.; Ahmed, N. Induction and extraction of $\beta$-carotene from the locally isolated Dunaliella salina. J. Algal Biomass Util. 2010, 1, 58-83.

90. Denery, J.R.; Dragull, K.; Tang, C.S.; Li, Q.X. Pressurized fluid extraction of carotenoids from Haematococcus pluvialis and Dunaliella salina and kavalactones from Piper methysticum. Anal. Chim. Acta 2004, 501, 175-181. [CrossRef]

91. Mendes, R.L.; Nobre, B.P.; Cardoso, M.T.; Pereira, A.P.; Palavra, A.F. Supercritical carbon dioxide extraction of compounds with pharmaceutical importance from microalgae. Inorg. Chim. Acta 2003, 356, 328-334. [CrossRef]

92. Ruegg, R. Extraction Process for Beta-Carotene in Patent. U.S. Patent 4,439,629, 27 March 1984.

93. Hejazi, M.A.; Kleinegris, D.; Wijffels, R.H. Mechanism of extraction of beta-carotene from microalga Dunaliellea salina in two-phase bioreactors. Biotechnol. Bioeng. 2004, 88, 593-600. [CrossRef]

94. Hejazi, M.A.; Wijffels, R.H. Milking of microalgae. Trends Biotechnol. 2004, 22, 189-194. [CrossRef]

95. Hejazi, M.A.; Wijffels, R.H. Effect of light intensity on beta-carotene production and extraction by Dunaliella salina in two-phase bioreactors. Biomol. Eng. 2003, 20, 171-175. [CrossRef]

96. Jaime, L.; Mendiola, J.A.; Ibáñez, E.; Martin-Alvarez, P.J.; Cifuentes, A.; Reglero, G.; Señoráns, F.J. Beta-carotene isomer composition of sub- and supercritical carbon dioxide extracts. Antioxidant activity measurement. J. Agric. Food Chem. 2007, 55, 10585-10590. [CrossRef]

97. Montero, O.; Macías-Sánchez, M.D.; Lama, C.M.; Lubián, L.M.; Mantell, C.; Rodríguez, M.; de la Ossa, E.M. Supercritical $\mathrm{CO}_{2}$ extraction of beta-carotene from a marine strain of the cyanobacterium Synechococcus species. J. Agric. Food Chem. 2005, 53, 9701-9707. [CrossRef] [PubMed]

98. Nobre, B.P.; Villalobos, F.; Barragán, B.E.; Oliveira, A.C.; Batista, A.P.; Marques, P.A.; Mendes, R.L.; Sovová, H.; Palavra, A.F.; Gouveia, L. A biorefinery from Nannochloropsis sp. Microalga-Extraction of oils and pigments. Production of biohydrogen from the leftover biomass. Bioresour. Technol. 2013, 135, 128-136. [CrossRef] [PubMed]

99. Wang, L.; Pan, B.; Sheng, J.; Xu, J.; Hu, Q. Antioxidant activity of Spirulina platensis extracts by supercritical carbon dioxide extraction. Food Chem. 2007, 105, 36-41. [CrossRef]

100. Gracia, I.; Rodríguez, J.F.; García, M.T.; Alvarez, A.; García, A. Isolation of aroma compounds from sugar cane spirits by supercritical $\mathrm{CO}_{2}$. J. Supercrit. Fluids 2007, 43, 37-42. [CrossRef]

101. Mendiola, J.A.; Santoyo, S.; Cifuentes, A.; Reglero, G.; IbÁÑEz, E.; SeÑOrÁNs, F.J. Antimicrobial Activity of Sub- and Supercritical $\mathrm{CO}_{2}$ Extracts of the Green Alga Dunaliella salina. J. Food Prot. 2008, 71, 2138-2143. [CrossRef]

102. Sathasivam, R.; Ki, J.S. A Review of the Biological Activities of Microalgal Carotenoids and Their Potential Use in Healthcare and Cosmetic Industries. Mar. Drugs 2018, 16, 26. [CrossRef]

103. Gateau, H.; Solymosi, K.; Marchand, J.; Schoefs, B. Carotenoids of Microalgae Used in Food Industry and Medicine. Mini Rev. Med. Chem. 2017, 17, 1140-1172. [CrossRef]

104. Yabuzaki, J. Carotenoids Database: Structures, chemical fingerprints and distribution among organisms. Database 2017, 2017 , bax004. [CrossRef]

105. Pourkarimi, S.; Hallajisani, A.; Alizadehdakhel, A.; Nouralishahi, A.; Golzary, A. Factors affecting production of beta-carotene from Dunaliella salina microalgae. Biocatal. Agric. Biotechnol. 2020, 29, 101771. [CrossRef]

106. Favas, R.; Morone, J.; Martins, R.; Vasconcelos, V.; Lopes, G. Cyanobacteria and microalgae bioactive compounds in skin-ageing: Potential to restore extracellular matrix filling and overcome hyperpigmentation. J. Enzym. Inhib. Med. Chem. 2021, 36, 1829-1838. [CrossRef]

107. Abd El-Hack, M.E.; Abdelnour, S.; Alagawany, M.; Abdo, M.; Sakr, M.A.; Khafaga, A.F.; Mahgoub, S.A.; Elnesr, S.S.; Gebriel, M.G. Microalgae in modern cancer therapy: Current knowledge. Biomed. Pharmacother. 2019, 111, 42-50. [CrossRef] [PubMed]

108. Ruperez, F.J.; Garcia-Martinez, D.; Baena, B.; Maeso, N.; Vallejo, M.; Angulo, S.; Garcia, A.; Ibañez, E.; Señorans, F.J.; Cifuentes, A.; et al. Dunaliella salina extract effect on diabetic rats: Metabolic fingerprinting and target metabolite analysis. J. Pharm. Biomed. Anal. 2009, 49, 786-792. [CrossRef] [PubMed]

109. El-Baz, F.K.; Salama, A.A.A.; Hussein, R.A. Dunaliella salina microalgae oppose thioacetamide-induced hepatic fibrosis in rats. Toxicol. Rep. 2019, 7, 36-45. [CrossRef]

110. El-Baz, F.K.; Saleh, D.O.; Abdel Jaleel, G.A.; Hussein, R.A. Attenuation of Age-Related Hepatic Steatosis by Dunaliella salina Microalgae in Senescence Rats through the Regulation of Redox Status, Inflammatory Indices, and Apoptotic Biomarkers. Adv. Pharmacol. Pharm. Sci. 2020, 2020, 3797218. [CrossRef] [PubMed]

111. Chidambara Murthy, K.N.; Vanitha, A.; Rajesha, J.; Mahadeva Swamy, M.; Sowmya, P.R.; Ravishankar, G.A. In vivo antioxidant activity of carotenoids from Dunaliella salina-A green microalga. Life Sci. 2005, 76, 1381-1390. [CrossRef] [PubMed]

112. Raja, R.; Hemaiswarya, S.; Balasubramanyam, D.; Rengasamy, R. Protective effect of Dunaliella salina (Volvocales, Chlorophyta) against experimentally induced fibrosarcoma on wistar rats. Microbiol. Res. 2007, 162, 177-184. [CrossRef]

113. Miranda, M.S.; Cintra, R.G.; Barros, S.B.; Mancini Filho, J. Antioxidant activity of the microalga Spirulina maxima. Braz. J. Med. Biol. Res. 1998, 31, 1075-1079. [CrossRef] 
114. Rao, A.R.; Sarada, R.; Baskaran, V.; Ravishankar, G.A. Antioxidant activity of Botryococcus braunii extract elucidated in vitro models. J. Agric. Food Chem. 2006, 54, 4593-4599. [CrossRef]

115. Manzocchi, E.; Guggenbühl, B.; Kreuzer, M.; Giller, K. Effects of the substitution of soybean meal by spirulina in a hay-based diet for dairy cows on milk composition and sensory perception. J. Dairy Sci. 2020, 103, 11349-11362. [CrossRef]

116. Robertson, R.C.; Guihéneuf, F.; Bahar, B.; Schmid, M.; Stengel, D.B.; Fitzgerald, G.F.; Ross, R.P.; Stanton, C. The Anti-Inflammatory Effect of Algae-Derived Lipid Extracts on Lipopolysaccharide (LPS)-Stimulated Human THP-1 Macrophages. Mar. Drugs 2015, 13, 5402-5424. [CrossRef]

117. Martins, C.B.; Ferreira, O.; Rosado, T.; Gallardo, E.; Silvestre, S.; Santos, L.M.A. Eustigmatophyte strains with potential interest in cancer prevention and treatment: Partial chemical characterization and evaluation of cytotoxic and antioxidant activity. Biotechnol. Lett. 2021, 43, 1487-1502. [CrossRef] [PubMed]

118. Ambrico, A.; Trupo, M.; Magarelli, R.; Balducchi, R.; Ferraro, A.; Hristoforou, E.; Marino, T.; Musmarra, D.; Casella, P.; Molino, A. Effectiveness of Dunaliella salina Extracts against Bacillus subtilis and Bacterial Plant Pathogens. Pathogens 2020, 9, 613. [CrossRef] [PubMed]

119. Levin, G.; Mokady, S. Antioxidant activity of 9-cis compared to all-trans beta-carotene in vitro. Free Radic. Biol. Med. 1994, 17, 77-82. [CrossRef]

120. Bechor, S.; Zolberg Relevy, N.; Harari, A.; Almog, T.; Kamari, Y.; Ben-Amotz, A.; Harats, D.; Shaish, A. 9-cis $\beta$-Carotene Increased Cholesterol Efflux to HDL in Macrophages. Nutrients 2016, 8, 435. [CrossRef]

121. Rotenstreich, Y.; Belkin, M.; Sadetzki, S.; Chetrit, A.; Ferman-Attar, G.; Sher, I.; Harari, A.; Shaish, A.; Harats, D. Treatment with 9-cis $\beta$-carotene-rich powder in patients with retinitis pigmentosa: A randomized crossover trial. JAMA Ophthalmol. 2013, 131, 985-992. [CrossRef]

122. Xu, Y.; Ibrahim, I.M.; Wosu, C.I.; Ben-Amotz, A.; Harvey, P.J. Potential of New Isolates of Dunaliella Salina for Natural $\beta$-Carotene Production. Biology 2018, 7, 14. [CrossRef]

123. Khoo, H.E.; Prasad, K.N.; Kong, K.W.; Jiang, Y.; Ismail, A. Carotenoids and their isomers: Color pigments in fruits and vegetables. Molecules 2011, 16, 1710-1738. [CrossRef] 